\title{
In Situ Hybridization Analysis of HPV 16 DNA Sequences
}

National Cancer Institute

\section{Source}

National Cancer Institute. In Situ Hybridization Analysis of HPV 16 DNA Sequences. NCI

Thesaurus. Code C87052.

An in situ hybridization diagnostic test utilizing fluorescent probes to detect HPV 16 DNA sequences in tissues. 